\title{
Phosphatase Activity of Microbial Populations in Different Milk Samples in Relation to Protein and Carbohydrate Content
}

\author{
Sosanka P. SANDILYA ${ }^{1}$, Anuradha GOGOI ${ }^{2}$, Pinky M. BHUYAN ${ }^{1}$, \\ Dip K. GOGOI* \\ ${ }^{1}$ Biotechnology Division, Central Muga Eri Research \& Training Institute, Central Silk Board, Jorhat, Assam \\ India; gkdeep@rediffmail.com (*corresponding author) \\ ${ }^{2}$ Sivasagar Regional Laboratory cum Office, Pollution Control Board Assam, Assam, India
}

\begin{abstract}
Cattle milk is a rich source of protein, carbohydrate, vitamins, minerals and all other major and micronutrients. At a moderate $\mathrm{pH}$, milk is an excellent media for the growth of microbes and thus, intake of raw milk is precarious. In this study, attempt was made for a qualitative study of eight raw milk samples of different varieties of cow and goat milk, collected from Jorhat district of Assam, India, on the basis of nutritional value and microbial population. The highest microbial population was found in the milk collected from cross hybrid variety of cow, whereas microbial contamination was the least in Jersey cow milk. Samples of C1 (Jersey cow) variety showed presence of the highest amount of protein and carbohydrate content as compared to the others. Almost all the milk samples showed positive acid and alkaline phosphatase activity. Maximum acid phosphatase activity was observed in cross hybrid cow milk, whereas local cow milk exhibited the highest alkaline phosphatase activity. Phosphatase activity did not show any co-relationship with microbial population of the milk samples. Similarly, the protein and carbohydrate content of the samples did not have any significant impact on both acid and alkaline phosphatase activity.
\end{abstract}

Keywords: alkaline phosphatase, acid phosphatase, cattle and goat milk, contamination

\section{Introduction}

Milk is one of the most nourished fluids secreted by mammals for the growth and development of their offspring. Due to the presence of all the major nutrients like protein, carbohydrate, vitamins, fats and minerals, it is considered to be as the nearly complete food for human being. The concentration of nutrients in milk varies within different environmental conditions, which results in major fluctuation among cattle milk from different parts of the globe (Soliman, 2005). Goat, universally known as the 'poor-man's cow' (Iqbal et al., 2008) plays a significant role in milk production and contributes to human nutrition in many developing countries (Devendra, 1999). According to Jost (2007), milk contains $87.30 \%$ water and the rest is composed of other nutrients like lactose, butter fat, casein, vitamins, albumin and globulin, minerals etc. Apart from that, the nutritive values of milk in different lactating mammals vary with better digestivity, alkalinity, buffering ability and even medicinal values (Park, 2006). Milk is normally collected from a lactating animal and is recognized as highly perishable food and thus an appropriate medium for the growth of diverse bacterial population. Some of the known bacterial species commonly found in milk are Streptococcus lactis, S. cremoris, Lactobacillus acidophilus, $L$. plantarum etc. In addition, a major amount of yeast, moulds and bacteriophages are also reported to be isolated from milk (Shubhangi et al., 2010). Some of them are benefic to mankind, whereas most of them are pathogenic and responsible for degradation of milk quality. The basic sources of microbial contamination are within the udder, from exterior of the teats and during the handling of milk and its storage equipments.

Phosphatase is an enzyme which under suitable conditions has the property of hydrolyzing organic phosphoric esters into inorganic phosphates (Roche, 1950). All types of raw milk contain alkaline phosphates in variable amounts. Amount of alkaline phosphate is not influenced by variety, breed, feed or fat content of milk. Alkaline phosphatase is an ubiquitous milk enzyme that historically has been used to verify adequate pasteurization of milk for public health purposes. Pasteurization temperature required for inactivation of alkaline phosphatase is recognized as safe for human consumption. Pulsed electric field (PEF) is a 
466

non-thermal alternative process that can be used for the treatment of raw milk in mild temperature for safety and shelf life of the heat-sensitive enzymes, nutrients and bioactive compounds (Shamsi et al., 2008).

The microbial content of milk is also affected by the cattles' health, environment, milking procedures and equipment sanitation, that can all can influence the level of microbial contamination of raw milk (Coorevits et al., 2008; Shubhangi et al., 2010). The milk holding temperature and length of milk storing time before testing and processing allow bacterial contaminants to multiply. All these factors will influence the total bacterial count and the types of bacteria present in raw milk. Here in this study, attempt has been made to analyze the quality of some raw milk samples of different cattle varieties from Jorhat district of Assam, India on the basis of nutritional, microbial population and phosphatase activity.

\section{Material and methods}

\section{Sample site and collection}

Eight raw milk samples were collected randomly from various locations of Jorhat district of Assam in sterilized sampling tubes, on the same day, and named as A1 (cross hybrid cow 1), A2 (cross hybrid cow 2), B1 (local cow 1), B2 (local cow 2), C1 (Jersey cow 1), C2 (Jersey cow 2), D1 (local goat 1) and D2 (local goat 2). The $\mathrm{pH}$ of the collected samples was recorded by following standard method (Eckert and Sims, 2009) and experiments were performed immediately after collection.

\section{Enumeration of bacterial population}

Enumeration of bacterial population was carried out by serial dilution spread plate technique by using Nutrient Agar Medium. In this process, an approximate amount of melted agar is poured into petri dishes under Laminar Air Flow system and allowed to solidify. After solidification, $200 \mu \mathrm{l}$ of cell suspension was uniformly spread over the media with the help of a glass spreader up to $10^{-7}$ dilution and allowed to incubate for 24,48 and $72 \mathrm{hrs}$, consecutively. The average $\mathrm{CFU} / \mathrm{ml}$ of the samples at $10^{-3}$ was then calculated out for observing the amount of microbial population among all the raw milk samples.

\section{Phosphatase activity}

Alkaline and acidic phosphatase assay was performed by following standard protocol (Eivazi and Tabatabai, 1977; Li et al., 2008). As such $0.2 \mathrm{ml}$ of Toluene is added to the 50 $\mathrm{ml}$ Erlenmeyer flask containing $1 \mathrm{ml}$ of raw milk sample, 4 $\mathrm{ml}$ of Modified Universal Buffer (MUB) with pH 6.5 and 9 for acidic and alkaline phosphatase respectively, along with $1 \mathrm{ml}$ of p-nitrophenyl phosphate solution made in the same buffer; the content was mixed by swirling (Lee, et al., 2004). The flask was then placed in an incubator at $37^{\circ} \mathrm{C}$ for 1 hour (Li et al., 2008) after proper sealing. Thereafter, $1 \mathrm{ml}$ of $0.5 \mathrm{M} \mathrm{CaCl}_{2}$ along with $4 \mathrm{ml}$ of $0.5 \mathrm{~N} \mathrm{NaOH}$ was added after removing the stopper. The flasks were swirled properly and the contents were filtered by using Whatman paper no. 2. The intensity of yellow colour developed in the filtrate was then measured at $420 \mathrm{~nm}$ wavelength with
Spectrophotometer. The amount of p-nitrophenol produced by phosphatase activity was calculated from the calibration graph of standard p-nitrophenol.

\section{Protein estimation}

Estimation of milk protein by standard curve was carried out as per the methodology developed by Lowry et al. (1951) and Zaia et al. (1999). The entire process is completed in three distinct steps. Firstly, 1\% Sodium Lauryl Sulfate (SLS) and 1\% Sodium Cholate was used in respective periods to disrupt the proteins from bacteria. Then, the direct reaction of protein with copper in alkaline medium yield $\mathrm{Cu}^{2+}$ peptide complex was observed, which is pure purple colored. The reaction of phosphomolybdate and phosphotungstide by tyrosine and tryptophan present in the treated protein in alkaline medium give a blue colored complex. The intensity of the color is proportional to the concentration of protein that was measured spectrophotometrically at $660 \mathrm{~nm}$ wave length.

\section{Carbohydrate estimation}

Carbohydrate content of milk was measured by hydrolyzing the polysaccharides into simple sugar through acid hydrolysis and estimating the resultant. In this study, the amount of carbohydrate present in the milk samples was estimated by following the Anthrone method as suggested by Thomas et al. (1956). Hydroxylmethylfurfural was formed due to dehydration of carbohydrate in higher $\mathrm{pH}$, which gets reacted with the anthrone to produce a blue colored complex. This is further measured at $630-650 \mathrm{~nm}$ under UV-vis-Spectrophotometer.

\section{Statistical Analysis}

The data provided herein are the mean values of the triplicate replications taken during the study. The arithmetic means of each sample against phosphatase activity and protein and carbohydrate content was calculated out and further analyzed for standard deviation. Correlation coefficient was determined at 0.01 level of significance using Statistical Analysis System and SPSS version 16.0.

\section{Results}

The $\mathrm{pH}$ of the eight raw milk samples was recorded immediately after collection and found in the ranges between 6.0 - 7.0. Enumeration of total viable colony $(\mathrm{cfu} / \mathrm{ml})$ in nutrient agar medium was recorded highest in sample no. A2 (1.8 $\times 10-4)$, whereas the least was observed in C1 (6x10-3), as shown in Tab. 1. Most of microbial colonies observed in agarized media plate belonged to bacterial communities. Gram positive rod shaped bacteria and gram negative cocci were predominant in the milk samples.

The samples were tested for both acid and alkaline phosphatase activity and their correlation with microbial population was determined. The alkaline phosphatase activity was found to be the highest in milk sample B1 (25.16 units $/ \mathrm{ml} / \mathrm{hr}$ ) followed by C2 (24.53 units $/ \mathrm{ml} / \mathrm{hr}$ ) whereas the acid phosphatase activity was found the highest in A2 (36.2 units $/ \mathrm{ml} / \mathrm{hr}$ ). 
Tab. 1. Enumeration of bacterial population in nutrient agar media

\begin{tabular}{ccccc}
\hline Types & Varieties & $\begin{array}{c}\text { Milk } \\
\text { Samples }\end{array}$ & Media Used & $\begin{array}{c}\text { Avg. } \\
\text { CFU/ml }\end{array}$ \\
\hline \multirow{2}{*}{ A } & Cross hybrid & A1 & & $1.7 \times 10^{-4}$ \\
& cow & A2 & & $1.8 \times 10^{-4}$ \\
\multirow{2}{*}{ B } & Local cow & B1 & & $9.5 \times 10^{-3}$ \\
& & B2 & Nutrient Agar & $1.4 \times 10^{-4}$ \\
C & Jersey cow & C1 & (HIMEDIA & $6 \times 10^{-3}$ \\
& & C2 & Ltd.) & $1.4 \times 10^{-4}$ \\
D & Local goat & D1 & & $1.3 \times 10^{-4}$ \\
& & D2 & & $8 \times 10-3$ \\
\hline
\end{tabular}

On the other hand, the amount of protein (28.72 $\mathrm{mg} / \mathrm{ml})$ and carbohydrate content $(72.61 \mathrm{mg} / \mathrm{ml})$ was found to be maximum in $\mathrm{C} 1$ variety of Jersey cow in comparison to the milk produced by other varieties of cattle (Figs. 1-4). The least amount of protein was found in raw milk sample A1 $(8.91 \mathrm{mg} / \mathrm{ml})$ and carbohydrate content was the lowest in A2 $(13.26 \mathrm{mg} / \mathrm{ml})$. Even though not with the highest values, goat milk samples had considerable amount of carbohydrate $(69.53 \mathrm{mg} / \mathrm{ml})$ and protein $(21.47$ $\mathrm{mg} / \mathrm{ml})$. The results revealed that acid, as well as alkaline phosphatase activity, are more intense in D1 sample of goat milk in comparison to the D2 variety (Figs. 1-4).

Statistical analysis of data showed that both acidic and alkaline phosphatase activity have got negative correlation ( $\mathrm{p} \otimes 0.01$ ) with protein and carbohydrate content of the raw milk samples (Tab. 2).

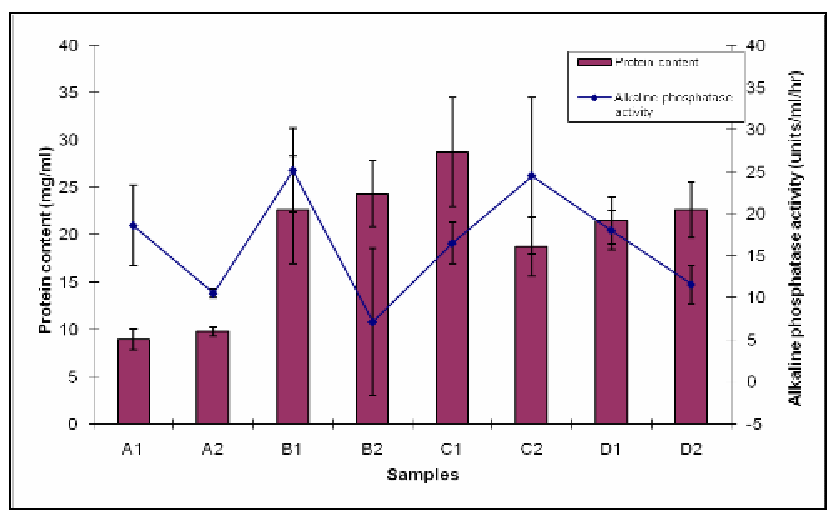

Fig. 1. Protein content in relation to alkaline phosphatase activity of the raw milk samples

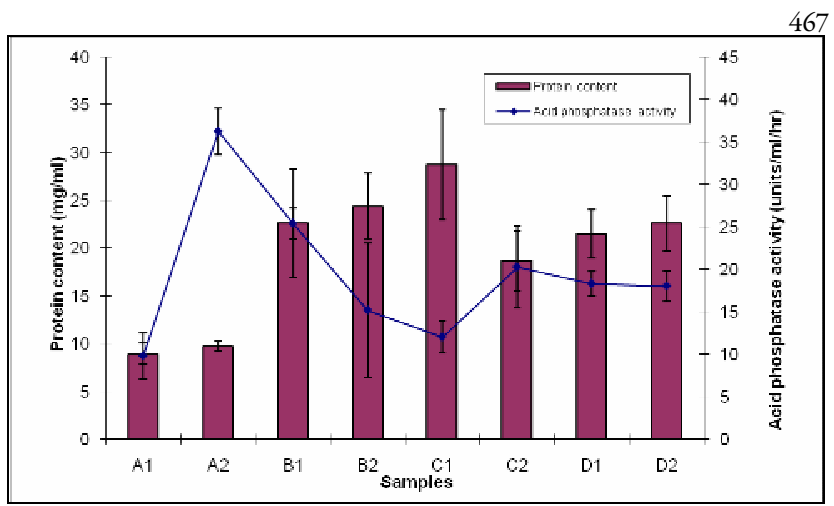

Fig. 2. Protein content in relation to acid phosphatase activity of the raw milk samples

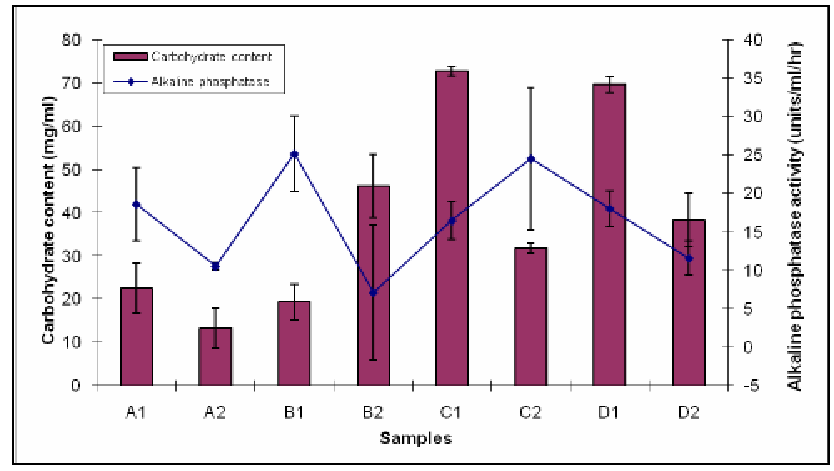

Fig. 3. Carbohydrate content in relation to alkaline phosphatase activity of the raw milk samples

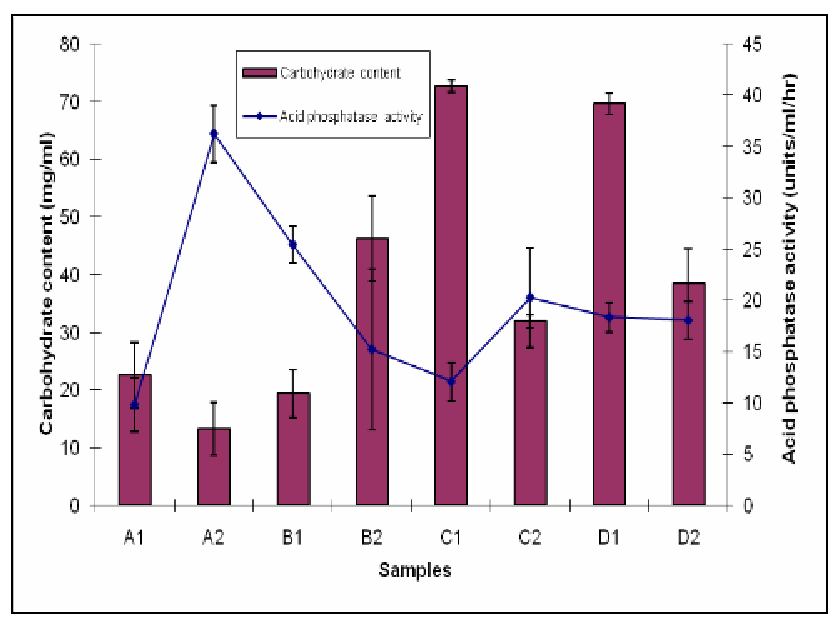

Fig. 4. Carbohydrate content in relation to acid phosphatase activity in the raw milk samples

Tab. 2. Correlation of alkaline and acid phosphatase activity with protein content

\begin{tabular}{cccc}
\hline \multirow{2}{*}{ Correlation/ Significance } & \multicolumn{2}{c}{ Alkaline phosphatase activity } & \multicolumn{2}{c}{ Acid phosphatase activity } & Carbohydrate & Carbohydrate & -0.114 \\
\cline { 2 - 4 } & Protein & -0.025 & -0.343 \\
\hline $\begin{array}{l}\text { Correlation } \\
\text { (Level 0.01) }\end{array}$ & -0.004 & 0.849 & 0.406 \\
$\begin{array}{l}\text { Significance } \\
\text { (Level 0.01) }\end{array}$ & 0.992 & 0.623 \\
\hline
\end{tabular}


468

\section{Discussion}

Milk is an excellent media for the growth of microbes due to its moderate $\mathrm{pH}$. Enumeration of microbial population in different milk samples of cattle revealed the microbial contamination in raw milk. The contamination may have resulted during the entire milking and collection procedure or due to infection in the udder. Most of the microbial colonies observed on the agarized plates were bacteria, while few of them were fungi. Some of the microorganisms present in the milk are benefic to human beings, but a mere contamination with pathogenic microorganisms is enough to create various types of dreaded diseases, and hence the consumption of milk without pasteurization is not recommended. More than $90 \%$ of the microbial population found in stored cold raw milk are gram-negative bacteria, primarily of psychrotrophic species, e.g. Pseudomonas, Achromobacter, Aeromonas, Serratia, Alcaligenes, Chromobacterium, Flavobacterium and Enterobacter etc. (Ryser, 1999; Martins et al., 2006; Torkar and Teger, 2008).

Milk is a rich source of nutrients for the growth and development of human beings (Joseph, 1981; Jost, 2007). Protein estimation result showed that the milk samples contain different amount of protein, ranging from 8.91 $\mathrm{mg} / \mathrm{ml}$ to $28.72 \mathrm{mg} / \mathrm{ml}$. Similarly, carbohydrate content of the milk also varies $(13.26 \mathrm{mg} / \mathrm{ml}$ to $72.61 \mathrm{mg} / \mathrm{ml})$ depending upon the varieties/races of the cow and goat individuals. It has been evidenced from the results that the protein and carbohydrate content is more in the milk produced by Jersey variety in comparison to the local and cross hybrid cattle milk. According to Park et al. (2007) milk has got two major and eight minor proteins and they play a crucial role in human diet. Consumption of $0.5 \mathrm{~L}$ of milk daily is the optimum level of a human body to satisfy himself with all the required quantity of amino acids (Tibulca and Jimborean, 2008).

In our study, significantly higher amount of protein and carbohydrate with alkaline phosphatase activity was recorded in D1 variety of goat milk. Compositions of goat milk vary with breed, diet, season, management, environmental conditions, locality, stage of lactation etc. (Park et al., 2007). Although goat milk has got lower protein and carbohydrate content than $\mathrm{C} 1$ variety of cow milk, it has better digestibility, alkalinity, buffering capacity and certain therapeutic values in medicine and human nutrition (Park and Chukwu, 1989; Park, 1994). Haenlein and Wendorff (2006) reported that specific gravity, titratable acidity and viscosity is higher in goat than in cow milk, whereas refractive index and freezing point is lower in goat than cow milk.

For characterization of raw milk, positive alkaline phosphatase result may be taken as an indicator of contamination (Chavarri et al., 1998; Rola and Sosnowski, 2010). Alkaline phosphatase activity for determination of the amount of microbial population in milk varies from one species to another (Sosnowski, 2012). The alkaline and acid phosphatase activity test showed the highest activity in local and Jersey cow respectively, leaving a moderate activity in the samples collected from local goat. The activity of phosphatase however decreases after heat treatment by almost 500 fold, as stated by Wilinska et al. (2007). Therefore, appropriate pasteurization would lead to inactivation of this enzyme further resulting into a purified product for consumption (Chavarri et al., 1998).

\section{Conclusion}

Our study reveals that, although the protein and carbohydrate content is promising for intake of the milk of different varieties of cattle and goat, due to the presence of high microbial population in the collected milk samples, it makes a forewarning against the consumption of raw milk. Hence, proper pasteurization of milk and dairy products is necessary for a hygienic intake. Appropriate attention should be focused during the handling of milk, to the disinfection of milking appliances, hygienic cattle rearing, cleaning of transportation tanks used for carrionh milk from collecting points to the dairies.

\section{References}

Chavarri F, Santisteban A, Virto M, Renobales M (1998). Alkaline Phosphatase, Acid Phosphatase, Lactoperoxidase, and Lipoprotein Lipase Activities in Industrial Ewe's Milk and Cheese. J Agric Food Chem 46(8):2926-2932.

Coorevits A, De Jonghe V, Vandroemme J, Reekmans R, Heyrman J, Messens W, De Vos P, Heyndrickx M (2008). Comparative analysis of the diversity of aerobic-sporeforming bacteria in raw milk from organic and conventional dairy farms. System App Microbiol 31(2):126-140.

Devendra C (1999). Goats: challenges for increased productivity and improved livelihoods. Outlook on Agriculture 28(4):215-226.

Eckert D, Sims JT (2009). Recommended Soil pH and Lime Requirement Tests. Cooperative Bulletin No. 493 Chapter 3:19-26.

Eivazi F, Tabatabai MA (1977). Phosphatases in soils. Soil Biol Biochem 9(3):167-172.

Haenlein GFW, Wendorff WL (2006). Sheep milk. production and utilization of sheep milk, p. 137- 194. In: Park YW, Haenlein GFW (Eds.). Handbook of Milk of Non-Bovine Mammals. Blackwell Publishing Professional, Oxford, UK, and Ames, Iowa, USA.

Iqbal A, Khan BB, Tariq M, Mirza MA (2008). Goat-A Potential Dairy Animal: Present and Future Prospects. Pak J Agr Sci 45(2):227-230.

Joseph PJ (1981). A Handbook of Animal Husbandry. $1^{\text {st }}$ ed. ICAR, New Delhi. p. 99.

Jost R (2007). Milk and Dairy Products. Ullmann's Encyclopedia of Industrial Chemistry. Wiley-VCH, Weinheim. doi:10.1002/14356007.a16_589.pub3.

Karmen GT, Slavica GT (2008). The microbiological quality of raw milk after introducing the two day's milk collecting system. Acta Agr Slovenica 92(1):61-74.

Lee JJ, Park RD, Kim YW, Shim JH, Chae DH, Rim YS, Sohn 
BK, Kim TH, Kim KY (2004). Effect of food waste compost on microbial population, soil enzyme activity and lettuce growth. Bioress Technol 93(1):21-28.

Li YF, Luo AC, Wei XH, Yao XG (2008). Changes in Phosphorus Fractions, $\mathrm{pH}$, and Phosphatase Activity in Rhizosphere of Two Rice Genotypes. Pedosphere 18(6):785-794.

Lowry OH, Rosenbrough NJ, Farr AL, Randall RJ (1951). Protein measurement with the Folin Phenol Reagent. J Biol Chem 193:265-275.

Martins ML, Pinto CLO, Rocha RB, Araujo EF, Vanetti MCD (2006). Genetic diversity of Gram-negative proteolytic, psychrotrophic bacteria isolated from refrigerated raw milk. Int J Food Microbiol 111:144-148.

Park YW (2006). Goat milk-chemistry and nutrition, p. 34-58. In: Park YW, Haenlein GFW (Eds.). Handbook of Milk of Non-Bovine Mammals. Blackwell Publishing Professional, Oxford, UK, and Ames, Iowa, USA.

Park YW (1994). Hypo-allergenic and therapeutic significance of goat milk. Small Rumin Res 14:151-161.

Park YW, Chukwu HI (1989). Trace mineral concentrations in goat milk from French-Alpine and Anglo-Nubian breeds during the first 5 months of lactation. J Food Compos Anal 2:161-169.

Park YW, Juarej M, Ramos M, Hanlein GFW (2007). Physicochemical characteristics of goat and sheep milk. Small Rum Res 68:88-113.

Roche J (1950). The Enzymes, p. 473-510. In: Sumner GB, Myrbiick K (Eds.). Academic Press, New York.

Rola GJ, Sosnowski M (2010). Determination of alkaline phosphatase activity in milk and milk products by fluorimetric method. Bull Vet Inst Pulawy 54:537-542.

Ryser E (1999). Microorganisms of importance in raw milk. Michigan Dairy Review 8:7-9.
Soliman GZA (2005). Comparison of chemical and mineral content of milk from human, cow, buffalo, camel and goat in Egypt. Egypt J Hosp Med 21:116-130.

Sosnowski MJ (2012). Alkaline phosphatase in cow and noncow milk and cheese- Determination of enzyme activity as an indicator for the completeness of the pasteurization process. Agro Food Ind Hi Tech 23(1):18-20.

Shamsi K, Versteeg C, Sherkat F, Wan J (2008) Alkaline phosphatase and microbial inactivation by pulsed electric field in bovine milk. Innovative Food Sci Emerg Technol 9(2):217-223

Shubhangi BK, Ghosh JS, Samudre SP (2010). Occurrence of Disease Causing Organisms Including Bacteriophages in Indigenous Fermented Milk Products. Advance J Food Sci Technol 2(4):196-199.

Thomas G, Hyman JVG (1956). The anthrone method for the determination of carbohydrates in food and in oral ringing. J Dent Res 35(1):109-116.

Torkar KG, Teger SG (2008). The Microbiological quality of raw milk after introducting the two day's milk collecting system. Acta Agri Slovenica 92(1):61-74.

Tibulca D, Jimborean MA (2008). Technology of dairy products. Risoprint Publishing House. Cluj-Napoca (in Romanian).

Wilinska A, Bryjak J, Illeova V, Polakovic M (2007). Kinetics of thermal inactivation of alkaline phosphatase in bovine and caprine milk and buffer. Inter Dairy J 176):579-586.

Zaia DAM, Verri WA Jr, Zaia CTBV (1999) Determination of total proteins: a study of reaction between quinones and proteins. Talanta 49:373-376. 